\title{
STRATEGI KEPALA MADRASAH UNTUK MENINGKATKAN PARTISIPASI MASYARAKAT DALAM BIDANG PENDIDIKAN DI MTs MA'HAD ISLAMY KOTA PAYAKUMBUH
}

\author{
Dasrul Fauzi \\ Mts Syekh Ibrahim Harun Tiakar, Payakumbuh Timur, Kota Payakumbuh \\ Korespondensi: Jl. Rasuna Said, Kelurahan Balai Batimah, Kota Payakumbuh, Sumatera Barat \\ e-mail: dasrulfauzi@yahoo.com
}

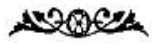

\begin{abstract}
The strategy of madrasab heads to increase public participation in the field of education is an important factor in determining education outcomes. The purpose of this study is: To find out the strategy of the head of the madrasah to increase public participation in the field of Education in MTs Ma'had Islamy Payakumbub City. Knowing the factors that influence the Head of Madrasah to increase public participation in the field of Education in MTs Ma'had Islamy Payakumbub City. This type of research is qualitative. Data sources used are primary data and secondary data. Data collection techniques through interviews, observation and documentation. The informants in this study consisted of principals, public relations officers, and teachers at MTs Ma'bad Islamy Payakumbuh City. Data analysis techniques in this study use data reduction, data presentation and data verification. The research results obtained are by holding meetings and establishing relationships with parents, visits to students 'bomes, correspondence, approaches through community leaders, publicity and madrasah socialization, bolding madrasa exbibitions, taking student reports and parents' involvement in the process learning. The forms of community participation in the MTs Ma'bad Islamy Payakumbuh City have been carried out including the participation of money and goods, labor and expertise participation, and mind participation. Factors influencing the madrasah chief's strategy in increasing community participation in MTs Ma'bad Islamy Payakumbub City are: Supporting factors which include the willingness and ability of individuals / communities, the opportunity of madrasas, high level of individual / community education, income or income from parents of students. The inbibiting factor is due to the location and access to madrasas that are quite far away, parents and the community who have their respective activities so it is difficult to take the time to attend the madrasa and lack of awareness of the surrounding environment and madrasas, services and appeals that are still limited because the lack of ability and intense communication between madrasa managers towards parents and the community.
\end{abstract}

Keywords: Strategi Kepala Madrasah, dan Mutu Pendidikan.

\section{PENDAHULAN}

Salah satu bentuk lembaga pendidikan Islam formal tingkat menengah pertama adalah sekolah yang terletak di Kota Payakumbuh. Yang tetap berkembang ditengah persaingan zaman di era Global ini. Ma'had Islamy adalah sebuah lembaga pendidikan yang telah berdiri sejak tahun 1930 (Dokumen: Sejarah Ma'had Islamy). Artinya lebih dari kurun setengah abad, sekolah berbasis Islam ini telah memberikan 
kontribusi bagi pendidikan dan sosial kemasyarakatan. Hal ini dibuktikan dengan banyaknya berdatangan para pelajar untuk menuntut ilmu dari berbagai wilayah di Indonesia (Dokumen: Sejarah Ma'had Islamy). Namun dewasa ini, seiring dengan bermunculannya sekolah-sekolah baru dengan pengelolaan yang lebih modern, MTs Ma'had Islamy mulai ditinggalkan sebagai pilihan bagi pendidikan anak-anak usia sekolah.

Dari sejarah yang penulis telusuri di MTs Ma'had Islamy, ternyata pada tahun 1935 keterlibatan dan partisipasi masyarakat sangat tinggi dalam memajukan serta mengangkat nama baik Ma'had Islamiy, dengan bantuan dari masyarakat Koto Nan Ampek, baik dalam bentuk tenaga, infaq, sedekah maupun zakat, akhirnya pada tahun 1934 gedung pendidikan Ma'had Islamy ini sudah menjadi lima ruangan dengan bangunan yang layak berlantai semen dan beratap seng (Dokumen: Sejarah Ma'had Islamy).

Berdasarkan pengamatan sementara dari penulis menemukan fenomenafenomena yang terjadi di MTs Ma'had Islamiy. Diantara fenomena tersebut adalah sebagai berikut: 1. Masih adanya masyarakat yang kurang sadar dan peduli terhadap pendidikan di sekitar mereka; 2. Banyaknya masyarakat yang kurang memberikan masukan dan usulan dalam pengembangan sekolah; dan 3. Kurang tersedianya sarana dan prasarana penunjang di sekolah. Hal ini sejalan dengan apa yang dikatakan oleh $\mathrm{Hj}$. Osriani “sebagian besar murid MTs Ma'had Islamy saat ini berasal dari luar Koto Nan Ampek, anak-anak disini lebih cendrung memilih masuk MTsN atau SMP dari pada
Ma'had Islamy" (Wawancara: 13 Januari 2018)

Ini tentunya menjadi fenomena tersendiri dari realita dan permasalahan yang telah dikemukakan di atas dimana hubungan madrasah dengan masyarakat secara education dan cultural khususnya orang tua murid dan masyarakat sekitar sekolah juga perlu direformasi sehingga tanggung jawab pendidikan bukan hanya pada madrasah. Adapun yang menjadi rumusan masalah penelitian ini adalah Bagaimana strategi kepala madrasah untuk meningkatkan partispasi masyarakat dalam bidang Pendidikan di MTs Ma'had Islamy Kota Payakumbuh. Sedangkan tujuan penelitian ini untuk mengetahui strategi kepala madrasah untuk meningkatkan partispasi masyarakat dalam bidang Pendidikan di MTs Ma’had Islamy Kota Payakumbuh.

\section{KAJ IANTEORTIS}

\section{Konsep Strategi}

Strategi adalah kunci suksesnya dalam mencapai tujuan madrasah. Kepala madrasah yang baik adalah kepala madrasah yang memiliki strategi jitu dalam memajukan madrasahnya. Tanpa ada strategi maka program madrasah tidak akan berjalan. Starategi adalah langkah awal dan terpenting ketika pemimpin berniat memajukan madrasah. Sehebat apapun seorang pimpinan jika ia tidak memiliki strategi yang baik dan jitu maka programnya akan tak berarti.

Kepemimpinan tidak hanya mengandalkan kemampuan sang pemimpin namun juga strategi sang pemimpin. Menurut David (2009: 5) strategis dapat 
didefinisikan sebagai seni dan pengetahuan dalam merumuskan, mengimplementasikan, serta mengevaluasi keputusan-keputusan lintasfungsional yang memampukan sebuah organisasi mencapai tujuannya. Seorang pimpinan dalam menerapkan suatu strategi harus menganalisis yang tepat tentang kekuatan yang dimiliki oleh organisasi, kelemahan yang mungkin melekat pada dirinya, berbagai peluang yang mungkin timbul dan harus dimanfatkan serta ancaman yang diperkirakan akan dihadapi.

Selanjutnya seorang pimpinan harus memperhatikan pentingnya operasionalisasi keputusan dasar yang dibuat dengan memperhitungan kemampuan organisasi di bidang anggaran, sarana, prasarana dan waktu, terakhir menciptakan umpan balik sebagai instrument ampuh bagi semua pihak yang terlibat dalam pelaksanaan strategi yang telah ditentukan itu untuk mengetahui apakah sasaran terlampaui, hanya sekedar tercapai atau mungkin bahkan tidak tercapai. Kesemuanya itu diperlukan sebagai bahan dan dasar untuk mengambil keputusan di masa depan.

\section{Strategi Kepala Madrasah dalam Meningkatkan Mutu Pendidikan}

Pengertian mengenai mutu pendidikan mengandung makna yang berlainan. Namun, perlu ada suatu pengertian yang operasional sebagi suatu pedoman dalam pengelolaan pendidikan untuk sampai pada pengertian mutu pendidikan, dari banyaknya pengertian mutu yang kita temuai dibuku-dibuku dapat disimpulkan bahwa mutu tersebut tidak hanya barang saja yang dapat diukur, tetapi mutu juga bermakna abstrat. Kita lihat terlebih dahulu pengertian mutu pendidikan.
Menurut Kamus Besar Bahasa Indonesia, (2008: 990) bahwa "Mutu adalah ukuran baik buruk suatu benda, keadaan, taraf atau derajad (kepandaian, kecerdasan, dan sebagainya)".

Mutu dapat dilihat dari dua sisi, yaitu seginormatif dan segi deskriptif, dalam artian normatif, mutu ditentukan berdasarkan pertimbangan (kriteria) intrinsik dan ekstrinsik. Berdasarkan kriteria intrinsik. Menurut Mulyasa, (2013: 22) Sedikitnya terdapat sepuluh kunci sukses kepemimpinan kepala madrasah tersebut mencakup: visi yang utuh, tanggung jawab, ketelanan, memberdayakan staf, mendengar orang lain, memberikan layanan terbaik, mengembangkan orang, fokus kepada peserta didik, memberdayakan madrasah, manajemen yang mengutamakan praktik, menyesuaiakan gaya kepemimpinan dan memanfaatkan kekuasaan keahlian.

\section{Partisipasi Masyarakat}

Partisipasi masyarakat merupakan salah satu bentuk keperdulian masyarakat atas penyelenggaraan pendidikan di sekolah. Partisipasi masyarakat berarti keterlibatan masyarakat dalam berbagai bentuk, seperti ide, saran, pendapat, dana, gagasan, keterampilan dan jasa. Keterlibatan mereka diarahkan dan ditujukan untuk meningkatkan kesadaran mereka akan hak dan tanggung jawab dalam dunia pendidikan. Adanya partisipasi aktif dari masyarakat ini diharapkan akan dapat mensukseskan program pendidikan yang telah dicanangkan. Dengan kata lain, keterlibatan atau partisipasi masyarakat dalam penyelenggaraan sekolah diperlukan agar sekolah dapat berfungsi dengan baik. 
Partisipasi masyarakat dalam penyelenggaraan pendidikan menurut Miarso (2004:709) ditujukan untuk:

1) Terbentuknya kesadaran masyarakat tentang adanya tanggung jawab bersama dalam pendidikan

2) Terselenggaranya kerjasama yang saling menguntungkan antara pihak yang berkepentingan dengan pendidikan.

3) Terciptanya efektivitas dan efisiensi dalam pemanfaatan sumber daya manusia, sumberdaya alam (lingkungan) dan sumberdaya buatan seperti dana, fasilitas, dan peraturan-peraturan.

4) Meningkatkan kinerja sekolah, yang berarti pula meningkatnya produktivitas, kesempatan memperoleh pendidikan, keserasian proses dan hasil pendidikan sesuai dengan kondisi anak didik dan lingkungan, serta komitmen dari para pelaksana pendidikan.

Partisipasi masyarakat dalam penyelenggaraan pendidikan di era otonomi ini merupakan wujud dari kesadaran pemilikan masyarakat akan keberadaan lembaga pendidikan yang kemudian mendorong menjadi rasa tanggung jawab untuk menciptakan sumber daya berkualitas. Tumbuhnya partisipasi aktif untuk membangun pendidikan yang bermutu dan mandiri merupakan pengimplementasian otonomi pendidikan sedangkan pemerintah hanya berfungsi sebagai fasilitator dan mitra kerja masyarakat. Salah satu wujud dari partisipasi tersebut adalah dengan dibentuknya komite sekolah.

\section{METODE PENEUTAN}

Populasi penelitian ini adalah kepala sekolah, guru, komite dan masyarakat yang berhubungan dengan M'Ts Ma'had Islamy Kota Payakumbuh. Sifat dari populasi ini adalah heterogen, karena sumber data memilik sifat atau keadaan yang berbeda (bervariasi) sehingga perlu ditetapkan batasbatasnya, baik secara kuntitatif dan kualitatif.

Sampel penelitian ini diambil dengan menggunakan teknik snowball sampling. Snowball sampling adalah teknik pengambilan sampel dengan bantuan key-informan, dan dari key informan inilah akan berkembang sesuai petunjuknya. Sampel tersebut akan menjadi key informan untuk selanjutnya memberikan petunjuk siapa informan dari kalangan Madrasah Tsanawiyah (MTs) Ma'had Islamy Kota Payakumbuh yang berkompeten memberikan data, mengingat sampel tersebut merupakan orang yang sering berinteraksi dengan masyarakat di Madrasah Tsanawiyah (MTs) Ma'had Islamy Kota Payakumbuh.

Teknik pengumpulan data sangat erat hubungannya dengan masalah penelitian yang ingin dipecahkan, masalah dapat memberi arah dan mempengaruhi penentuan metode pengumpulan data karena banyak metode untuk memperoleh data yang diperoleh tidak dapat menghasilkan data seperti yang diinginkan. Ada beberapa cara teknik pengumpulan data menurut Bungin, (2007:108) yaitu sebagai berikut: “(1) Wawancara, (2) Observasi, (3) Dokumentasi".

Analisa data yang didapat dari penelitian dianalisa dengan menggunakan analisis data model Miles and Huberman. Dimana, Miles dan Huberman dalam 
Sugiyono (2012: 91) mengemukakan bahwa aktivitas dalam analisis data kualitatif dilakukan secara interaktif dan terus menerus sampai tuntas, hingga datanya jenuh.

\section{HASIL PENEIUTIANDANPEMBAHASAN}

\section{Hasil Penelitian}

1. Strategi Kepala Madrasah untuk Meningkatkan Partispasi Masyarakat dalam bidang Pendidikan di MTs Ma'had Islamy Kota Payakumbuh.

Madrasah dan masyarakat merupakan dua komunitas yang saling melengkapi antara satu dengan yang lainnya. Madrasah berperan dalam melestarikan dan memindahkan nilai-nilai kultur pendidikan, ilmu pengetahuan, teknologi, dan agama yang dianut para guru dan peserta didiknya kepada generasi penerus untuk menjamin kemajuan ilmu pengetahuan dan kemajuan sosial dengan menjadi pelaku aktif dalam perbaikan masyarakat. Madrasah merupakan bagian yang tidak terpisahkan dengan masyarakat, bahkan madrasah tumbuh dan berkembang sesuai dengan tuntutan dan harapan masyarakat.

Berdasarkan hasil wawancara dan penelitian dapat diketahui bahwa strategi kepala madrasah dalam meningkatkan partisipasi orang tua dan masyarakat di MTs Ma'had Islamy Kota Payakumbuh melalui:

a. Mengadakan pertemuan dan menjalin silaturahmi dengan orang tua murid dan masyarakat.

Pertemuan wali murid ini merupakan salah satu bentuk komunikasi dilakukan oleh MTs Ma'had Islamy Kota Payakumbuh. Kegiatan pertemuan semacam ini sangat diperlukan untuk terus menumbuhkan rasa kebersamaan dan kepercayaan kedua belah pihak.

Agenda dalam pertemuan yang di jadwalkan 2 kali satu tahun ini yang sering dibahas adalah tentang bantuan operasional dan UPM (Upaya Pengembangan Madrasah). Dengan melibatkan orang tua dalam pertemuan wali murid yang tergabung dalam Persatuan Orang Tua Murid (POM) dengan madrasah dapat menjalin silaturahmi dan kerjasama yang harmonis antara madrasah dan orang tua.

b. Kunjungan ke rumah murid yang dilakukan pihak madrasah.

Kegiatan kunjungan rumah yang diadakan oleh MTs Ma'had Islamy Kota Payakumbuh ini jika ada murid yang tidak masuk selama seminggu atau lebih karena sakit, untuk memecahkan masalah dan mengembangkan pribadi peserta didik dan ketika salah satu dari orang tua murid mendapatkan musibah (meninggal dunia). Hal ini merupakan wujud belasungkawa dari MTs Ma'had Islamy Kota Payakumbuh terhadap orang tua siswa atau masyarakat sekitar yang meninggal dunia.

Dengan adanya kunjungan walikelas ke rumah murid dimaksudkan agar terdapat saling kepedulian antara orang tua murid dengan madrasah, sehingga madrasah benar-benar berperan aktif dalam setiap kejadian yang terdapat dalam masyarakat.

c. Melakukan Pendekatan melalui tokoh masyarakat yang cukup berpengaruh.

Salah satu langkah yang baik ditempuh oleh kepala madrasah dalam 
meningkatkan partisipasi masyarakat adalah menggunakan tokoh masyarakat yang cukup berpengaruh untuk ikut serta dalam kegiatan madrasah, seperti mengundang dokter umum sebagai narasumber dalam seminar kesehatan madrasah untuk program madrasah dengan mengajak masyarakat sekitar dan tentunya madrasah untuk mengikuti kegiatan yang cukup pentingagar dapat mengetahui seputar dunia kesehatan maupun pendidikan.

d. Publisitas dan sosialisasi madrasah.

Upaya lainnya yang diterapkan kepala MTs Ma'ahad Islamy Kota Payakumbuh untuk meningkatkan partisipasi masyarakat adalah dengan publisitas atau sosialisasi. Dengan cara ini MTs Ma'had Islamy Kota Payakumbuh bekerjasama dengan berbagai media baik elektronik maupun cetak.

Sebagaimana yang telah dilakukan oleh MTs Ma'had Islamy Kota Payakumbuh yang menjalin kerjasama dengan stasiun radio swasta dan surat kabar. Sebagai contoh, MTs Ma'had Islamy Kota Payakumbuh telah bekerjasama dengan Beritasumbar.com untuk mempublikasikan kegiatan yang dilakukannya, seperti debat kandidat calon ketua osis MTs Ma'had Islamy Kota Payakumbuh dan penerimaan peserta didik baru. Selain itu madrasah telah memiliki blog sendiri dan mengembangkan akun sosial media facebook yangdilindungi untuk kepentingan sosialisasi madrasah kepada masyarakat mengenai kegiatan dan program madrasah. e. Menawarkan atau Memberikan Kesempatan kepada Masyarakat untuk Berpartisipasi.

Adapun cara yang dilakukan Kepala Madarasah dalam meningkatkan partisipasi masyarakat adalah dengan menawarkan atau memberikan kesempatan kepada masyarakat untuk berpartisipasi, menerapkan manajemen madrasah yangterdiri dari perencanaan dalam penyusunan visi, misi, tujuan dan program madrasah bersama masyarakat, pengorganisasian yang dilembagakan dalam bendahara dan dewan madrasah, pelaksanaan dalam keikut sertaan rapat di madrasah, dan mengawasi proses pendidikan, melakukan persuasi atau mengajak masyarakat bahwa ketelibatan mereka dalam pendidikan dapat menguntungkan mereka juga.

2. Bentuk-bentuk partispasi masyarakat dalam bidang Pendidikan di MTs Ma'had Islamy Kota Payakumbuh

a. Partisipasi dalam bentuk uang dan barang Pada tingkat (madrasah) satuan pendidikan, biaya pendidikan diperoleh dari subsidi pemerintah pusat, pemerintah daerah, iuran siswa, dan sumbangan masyarakat. Sejauh tercatat dalam rencana anggaran pendapatan dan belanja madrasah (RAPBS), sebagian besar biaya pendidikan ditingkat madrasah berasal dari pemerintah pusat sedangkan madrasah swasta berasal dari para siswa atau yayasan.

MTs Ma'had Islamy Kota Payakumbuh adalah salah satu lembaga pendidikan berasaskan Islam yang juga menerapkan hubungan sosial dengan 
orang tua/wali murid dan masyarakatsekitar demi kelancaran pendidikan.

Berdasarkan wawancara yang dilakukan wujud dukungan atau partisipasi orang tuasiswa MTs Ma'had Islamy Kota Payakumbuh diwadahi oleh bendahara madrasah. Melalui bendahara madrasah orang tua siswa menentukan kisaran besar dan kecilnya dana sumbangan dana pendidikan. Partisipasi yang berbentuk dana ini tidak mudah diberikan oleh orang tua siswa dan masyarakat tanpa kesadaran terhadap pendidikan dan karena adanya pengetahuan orang tua dan masyarakat tentang madrasah gratis. Selain itu pihak madrasah telah membuat program kelas unggulan untuk siswa-siswi yang berprestasi didalam pendidikan dengan cara meminta bantuan serta dukungan orang tua dan masyarakat untuk terlibat dalam pengadaan fasilitas pembelajarannya.

b. Partisipasi tenaga dan keahlian

Selain berbentuk materi partisipasi masyarakat yang dapat diberikan oleh orang tua dan masyarakat kepada madrasah dapat berupa tenaga.

Jika dilihat dari latar belakang pendidikan terakhir, tenaga pendidik akademis yang ada di madrasah ini, ratarata mereka telah berhasil menempuh jenjang pendidikan S2 dan S1 dengan berbagai kualitas dan kompetensi yang mumpuni sehingga tak mengherankan jika pihak madrasah jarang mengikut sertakan orangtua untuk membantu dalam pelaksanaan belajar mengajar di madrasah.
Meskipun begitu ada juga partisipasi yang diberikan oleh masyarakat yang berbentuk tenaga yang berasal dari pengusaha meubel ukiran kayu yang ingin berpartisipasi terhadap MTs Ma'had Islamy Kota Payakumbuh lewat keahlian dan profesi yang ditekuninya. Dia mengajak siswa MTs Ma'had Islamy Kota Payakumbuh mendatangi usaha meubelukiran kayu tersebut lalu siswa belajar cara membuat dan hingga pemasarannya.

c. Partisipasi Fikiran

Perubahan dan perkembangan madrasah akan terjadi manakala ada keikutsertaan masyarakat dalam bentuk pemikiran dan kebijakan di madrasah.

Berdasarkan hasil penelitian pihak madrasah juga telah menyediakan buku notulen rapat dan daftar hadir rapat ketika akan mengadakan rapat dengan dewan guru dan mengundang orang tua untuk ikut terlibat menentukan kebijakan di madrasah. Orang tua dan masyarakat biasanya hadir ke madrasah ketika menerima undangan resmi dari pihak madrasah jika akan mengadakan pertemuan, namun tidak dapat dipungkiri juga karena sebagian ada siswa yang tinggal jauh dari orang tuanya dan kesibukan masing-masing orang tua seringkali membuat mereka tidak bisa hadir.

3. Faktor yang mempengaruhi strategi kepala madrasah untuk meningkatkan partispasi masyarakat dalam bidang Pendidikan di MTs Ma'had Islamy Kota Payakumbuh 
Keterlibatan masyarakat dan orang tua dalam lembaga pendidikan tentunya disebabkan oleh faktor-faktor pendukung yang dalam penelitian ini adalah faktor internal maupun eksternal. Menurut Kepala MTs Ma'had Islamy Kota Payakumbuh bapak Arif Hidayat, S. Sos mengatakan bahwa faktor internal yang mempengaruhi partisipasi masyarakat di madrasah yaitu:

a. Adanya kemauan dan kemampuan

Keikutsertaan seseorang dalam suatu kegiatan di madrasah bukan timbul begitu saja akan tetapi karena ada yang mendorongnya untuk partisipasi. Orang tua dan masyarakat memiliki kesibukan yang bermacam-macam sehingga untuk membuat mereka berpartisipasi bukanlah suatu hal yang mudah, melainkan adanya kemauan dan kesadaran yang berasal dari mereka sendiri untuk ikut terlibat dalam penyelenggaraan pendidikan di madrasah. Kemampuan tersebut dapat melalui kecerdasan, pengetahuan dan komunikasi yang baik dalam berpartisipasi.

b. Adanya kesempatan

Madrasah sebagai wadah yang menampung aspirasi orang tua dan masyarakat telah menawarkan dan memberikan kesempatan sebesar-besarnya kepada orang tua dan masyarakat yang mau terlibat dalam kegiatan dan proses pendidikan di madrasah baik itu dari segi perumusan dan pengambilan keputusan bersama masyarakat dan pelaksanaan pendidikan di madrasah.

Dengan memberikan kesempatan kepada masyarakat untuk berpartisipasi diharapkan dapat menumbuhkan kesadaran akan pentingnya masyarakat untuk terlibat dalam penyelenggaraan pendidikan.

c. Tingkat Pendidikan

Pendidikan dapat dikatakan sebagai salah satu syarat mutlak untuk berpartisipasi. Salah satu faktor yang menyebabkan terjadinya berbagai perubahan atau gerakan masyarakat untuk berpartisipasi adalah karena tingkat pendidikan. Masyarakat yang memiliki tingkat pendidikan yang cukup tinggi biasanya mempunyai perhatian yang besar terhadap penyelenggaraan pendidikan yang dilakukan di madrasah.

d. Penghasilan/Pendapatan

Pendapatan orang tua dan masyarakat juga cukup berpengaruh khususnya dalam bentuk sumbangan dana/uang dalam meningkatkan fasilitas pendidikan di madrasah. Penghasilan masyarakat dan orang tua siswa yang berbeda sangat memungkinkan jika ada orang tua siswa yang memiliki kondisi financial yang baik maka mudah saja bagi mereka menyumbangkan uangnya untuk pengembangan fasilitas madrasah. Namun sebaliknya orang tua yang kondisi keuangan sehari-harinya tergolong rendah, maka untuk biaya pendidikan juga cukup sulit dikeluarkan.

\section{Pembahasan}

Strategi yang dilakukan oleh Kepala MTs Ma'had Islamy Kota Payakumbuh yakni dengan mencari mitra kerjasama dengan instansi lain. Sama halnya dengan pemaparan pada Peraturan Menteri Pendidikan Nasional atau Permendiknas Nomor 13 Tahun 2007 tentang Standar Kepala Madrasah/ Madrasah disebutkan 
bahwa terdapat 5 dimensi kompetensi seorang kepala madrasah, salah satunya yakni kompentensi sosial, Kepala MTs Ma'had Islamy Kota Payakumbuh sudah mempunyai kompetensi sosial, karena sudah bisa membangun mitra kerjasama dengan instansi lain, seperti puskesmas setempat.

Keterbukaan informasi kepada masyarakat maupun orangtua peserta didik, termasuk dalam layanan murid dan salah satu faktor yang mempengaruhi ketercapaian tujuan pendidikan di madrasah. Strategi tersebut dilakukan Kepala MTs Ma'had Islamy Kota Payakumbuh dalam rangka meningkatkan pemaksimalan layanan yang diberikan madrasah kepada peserta didik, masyarakat maupun orangtua peserta didik. Sesuai dengan Petunjuk Pelaksanaan Penilaian Potensi Kepemimpinan Calon Kepala Madrasah/Madrasah (2011: 6), bahwa kepemimpinan pendidikan merupakan kemampuan menggerakkan faktorfaktor yang mempengaruhi ketercapaian tujuan pendidikan di madrasah.

Penyusunan program hubungan madrasah dengan masyarakat di MTs Ma'had Islamy Kota Payakumbuh melibatkan kepala madrasah, guru, dan karyawan atau tata usaha. Sedangkan untuk pengesahan, komite madrasah terlibat didalamnya sebagai pihak yang menyetujui. Sesuai dengan Peraturan Menteri Pendidikan dan Kebudayaan Republik Indonesia No. 75 Tahun 2016 Tentang Komite Madrasah Pasal 3 Ayat 1, bahwa memberikan pertimbangan dalam penentuan dan pelaksanaan kebijakan pendidikan terkait: (1) kebijakan dan program Madrasah, (2) Rencana Anggaran Pendapatan dan Belanja Madrasah/Rencana Kerja dan Anggaran Madrasah
(RAPBS/RKAS), (3) kriteria kinerja Madrasah, (4) kriteria fasilitas pendidikan di Madrasah, dan (5) kriteria kerjasama Madrasah dengan pihak lain. Salah satu peran komite madrasah yakni memberi pertimbangan, peran komite dalam hal ini sebagai pemberi pertimbangan dalam upaya peningkatan mutu pembelajaran dengan memberikan pertimbangan dalam upaya peningkatan mutu pembelajaran dalam kebijakan dan program madrasah dengan terlibat dalam memberikan pertimbangan pada pembahasan RKAS, RAPBS, dan kurikulum madrasah.

Komite madrasah di MTs Ma'had Islamy Kota Payakumbuh memberikan pertimbangan ketika penyusunan program itu sudah selesai. Rahayu, dkk (2014: 235) keberhasilan madrasah dalam melaksanakan program pendidikan dan pengembangan perlu didukung dengan efektifitas kepemimpinan pendidikan yang dijalankan oleh eksekutif lembaga pendidikan khususnya para kepala madrasah, pengawas, maupun administrator lain yang diberi tugas dan tanggungjawab untuk mengambil inisiatif pelaksanaan fungsi kepemimpinan yang pendidikan di madrasah. Sesuai dengan penyusunan program hubungan madrasah dan masyarakat yang dilakukan di MTs Ma'had Islamy Kota Payakumbuh ketika menyusun program melibatkan pihak-pihak yang ada di madrasah seperti kepala madrasah, guru dan karyawan/tata usaha.

Salah satu kendala yang dihadapi oleh Kepala MTs Ma'had Islamy Kota Payakumbuh, yakni latar belakangan perekonomian madrasah ini menengah ke bawah, dan kesibukkan dari masing-masing pihak, seperti kepala madrasah, komite 
madrasah dan orangtua peserta didik. Solusi dari kendala tersebut adalah mengkomunikasikan program yang akan dilaksanakan oleh madrasah kepada masyarakat sekitar melalui tokoh masyarakat, orangtua melalui surat pemberitahuan. Sesuai dengan pendapat Dwiningrum (2011: 218) partisipasi yang ada di madrasah partisipasi non fisik yang ada di madrasah seperti memberikan bantuan tanpa harus mengeluarkan tenaga dan mengurangi waktu. Solusi Kepala MTs Ma'had Islamy Kota Payakumbuh dari masyarakat dan orangtua yang pasif yakni dengan mengkomunikasikan program yang akan dilaksanakan oleh madrasah kepada masyarakat sekitar melalui tokoh masyarakat, orangtua melalui surat pemberitahuan. salah satu karakteristik menurut Tjiptono dan Diana yakni ketrampilan komunikasi, Kepala MTs Ma'had Islamy Kota Payakumbuh cakap dalam berkomunikasi menyampaikan informasi maupun membenarkan informasi yang terkadang salah persepsi di masyarakat maupun orangtua peserta didik, tidak hanya dengan masyarakat dan orangtua peserta didik saja Kepala MTs Ma'had Islamy Kota Payakumbuh berkomunikasi melainkan dengan guru yang belum bisa akrab dengan lingkungan sekitar.

Salah satu cara yang dilakukan oleh Kepala MTs Ma'had Islamy Kota Payakumbuh yakni, mengkomunikasikan segala bentuk kegiatan atau kendala kepada masyarakat maupun orangtua peserta didik dan paguyuban dan komite madrasah agar tidak terjadi kesalahan informasi antar pihak. Upaya madrasah mengkomunikasikan semua hal yang ada di madrasah merupakan salah satu kunci agar madrasah dapat dipercaya oleh masyarakat maupun orangtua. Mustiningsih (2013: 33) terdapat beberapa pengertian kepemimpinan pendidikan yakni, (1) mampu menumbuhkan dan mengembangkan segala yang terbaik dalam diri bawahannya, (2) dapat mempengaruhi orang lain atau kelompok untuk melakukan unjuk kerja maksimum, (3) dengan kekuasaannya mampu menggugah pengikutnya untuk mencapai kinerja yang memuaskan, (4) memberikan manfaat bagi yang dipimpin dan bagi lembaga/organisasinya, (5) berani menghadapi situasi tertentu dalam organisasinya. Berdasarkan strategi Kepala MTs Ma'had Islamy Kota Payakumbuh dalam mempertahankan partisipasi masyarakat dengan komunikasi, sesuai dengan pendapat Mustiningsih bahwa seorang pemimpin pendidikan dapat mempengaruhi orang lain atau kelompok untuk melakukan unjuk kerja maksimum, disamping kepala madrasah meningkatkan komunikasi juga dapat mempengaruhi masyarakat maupun orangtua peserta didik untuk berpartisipasi dalam program madrasah.

\section{PENUTUP}

\section{Kesimpulan}

Berdasarkan pada bab terdahulu maka penulis dapat menarik suatu kesimpulan sebagai berikut:

1. Strategi kepala madarasah dalam meningkatkan partisipasi masyarakat di MTs Ma'had Islamy Kota Payakumbuh dengan cara menjalin silaturahmi dan musyawarah pada saat pertemuan dengan orang tua murid, kunjungan ke rumah murid, surat menyurat, pendekatan melalui tokoh masyarakat, publisitas dan 
sosialisasi madrasah dan pengambilan raport siswa melalui orang tua/wali murid.

2. Bentuk-bentuk partisipasi masyarakat pada MTs Ma'had Islamy Kota Payakumbuh sudah cukup baik. Adapun bentuk dukungan yang diberikan tersebut berupa partisipasi uang dan barang, partisipasi tenaga dan keterampilan serta partisipasi pikiran.

3. Faktor-faktor yang mempengaruhi partisipasi masyarakat di MTs Ma'had Islamy Kota Payakumbuh, adalah sebagai berikut: faktor pendukung yang meliputi adanya kemauan dan kemampuan dari dalam diri individu / masyarakat yang ingin berpartisipasi, pihak madrasah senantiasa memberikan kesempatan kepada orang tua dan masyarakat untuk berpartisipasi dalam penylenggaraan pendidikan di madrasah, tingkat pendidikan yang tinggi dan penghasilan atau pendapatan dari orang tua siswa yang beragam. Sedangkan faktor penghambatnya meliputi lokasi dan akses ke madrasah yang cukup jauh, orang tua dan masyarakat yang memiliki kesibukan masing-masing sehingga sulit meluangkan waktu untuk hadir ke madrasah untuk kegiatan diskusi atau rapat, serta pelayanan maupun himbauan yang masih terbatas karena minimnya kemampuan dan komunikasi yang intens antara pengelola madrasah terhadap orang tua siswa maupun masyarakat luar.

\section{Saran}

1. Diharapkan kepada kepala MTs Ma'had Islamy Kota Payakumbuh untuk dapat mengerti dan memenuhi kebutuhan madrasah, memfungsikan semua staf dan guru dengan baik, serta memiliki keterbukaan dan menghimbau kepada orang tua dan masyarakat untuk menjadi bagian dalam penyelenggaraan pendidikan di madrasah.

2. Diharapkan tenaga pendidik dan seluruh civitas akademik MTs Ma'had Islamy Kota Payakumbuh untuk lebih meningkatkan kebersamaan dan kerjasama kepada orang tua murid dalam meningkatkan pembelajaran peserta didik secara tematik dan berkesinambungan.

3. Diharapkan kepada orang tua murid dan masyarakat dapat lebih berinisiatif untuk melibatkan diri dalam kegiatan pendidikan yang ada di madrasah.

\section{KEPUSTAKAANACUN}

Ali, Lukman (2008), Kamus Besar bahasa Indonesia. Jakarta: Balai Pustaka, Cet. $\mathrm{Ke}-4$

Ali, Zainuddin (2008). Hukum Perbankan Syariah. Jakarta: Sinar Grafika.

Anwan, Moch Idochi. (2013). Administrasi Pendidikan dan Manajemen Pembiayaan Pendidikan. Jakarta: RajaGrafindo Persada.

Bungin, Burhan (2007). Penelitian Kualitatif: Komunikasi, Ekonomi, Kebijakan Publik dan Ilmu Sosial lainnya. Jakarta:Putra Grafika

Bungin, Burhan. (2007). Metodelogi Peelitian Kualitatif. Jakarta: Raja Grafindo Persada.

David, Fred. (2009). Manajemen Strategi. Jakarta: Salemba Empat.

Harun, Cut Zahri. (2009). Manajemen Sumber Daya Pendidikan. Yogyakarta: Pena Persada Dekstop Publisher. 
Miarso, Yusufhadi (2004). Menyemai Benih Teknologi Pendidikan. Jakarta: Prenada Media

Mulyasa, E. (2013). Manajemen Dan Kepemimpinan Kepala Madrasah. Jakarta: BumiAksara.

Murniati, AR. (2010). Manajemen Stratejik Peran Kepala Madrasab Dalam
Pemberdayaan. Bandung: Cipta Pustaka Media Perintis.

Sallis, Edward. (2010. Total Quality Manajement in Education. Yogyakarta: PT IRCiSoD.

Sugiyono (2012). Metode Penelitian Kuantitatif Kualitatif dan R\&D. Bandung: Alfabeta 